\title{
Lenape-Colonist Land Conveyances in West New Jersey: \\ Evolving Expectations in Space and Time
}

\section{By Jean R. Soderlund and Claude M. Epstein}

\section{DOI: http://dx.doi.org/10.14713/njs.v4i2.129}

European colonizers and Lenape Indians brought different expectations to treaty conferences regarding land. Analysis of West New Jersey deeds and related documents shows how the Dutch, Swedes, and English in West New Jersey-like fellow colonists in East Jersey-sought full ownership of territory first along the bays, rivers, and mouths of large streams to access trade, transportation, and arable land, then moved inland. While the deeds were European documents, close scrutiny shows how the Lenapes of southern and western New Jersey delayed European takeover by imposing their own norms. The Lenapes viewed the conveyances as leases, expecting annual payments and actual settlement for continued tenure. ${ }^{1}$

The process by which the Lenape Indians lost control of the territory now called New Jersey unfolded in four river systems and along the Atlantic coast over a period of one hundred and thirty years, from 1624 to 1758 . Documentary records including deeds and court records reveal the shift from Lenape power as European colonists took up lands in the East Jersey region, comprising the Hackensack, Passaic, and Raritan river basins and the northern seacoast; and in West New Jersey, incorporating the Delaware River basin and southern Atlantic shore (Figure 1). As scholar Robert S. Grumet has shown, the Munsees (northern Lenapes) of northern and eastern New Jersey suffered serious population loss before 1650 from epidemics and Kieft's War with the Dutch, undermining

\footnotetext{
${ }^{1}$ We would like to thank Robert Barnett, Mark Demitroff, Bonnie Beth Elwell, Edward Fox, Peter Hamilton, David Larsson, Douglas McVarish, Paul W. Schopp, Robert Shinn, Robert Thompson, Richard Watson and the anonymous readers for New Jersey Studies for their insightful suggestions for this paper.
} 
their ability to resist European encroachment. ${ }^{2}$ The Lenapes of southern and western New Jersey held power longer, avoiding large-scale war and dominating the Dutch, Swedish, and English colonizers until the late seventeenth century.

Figure 1

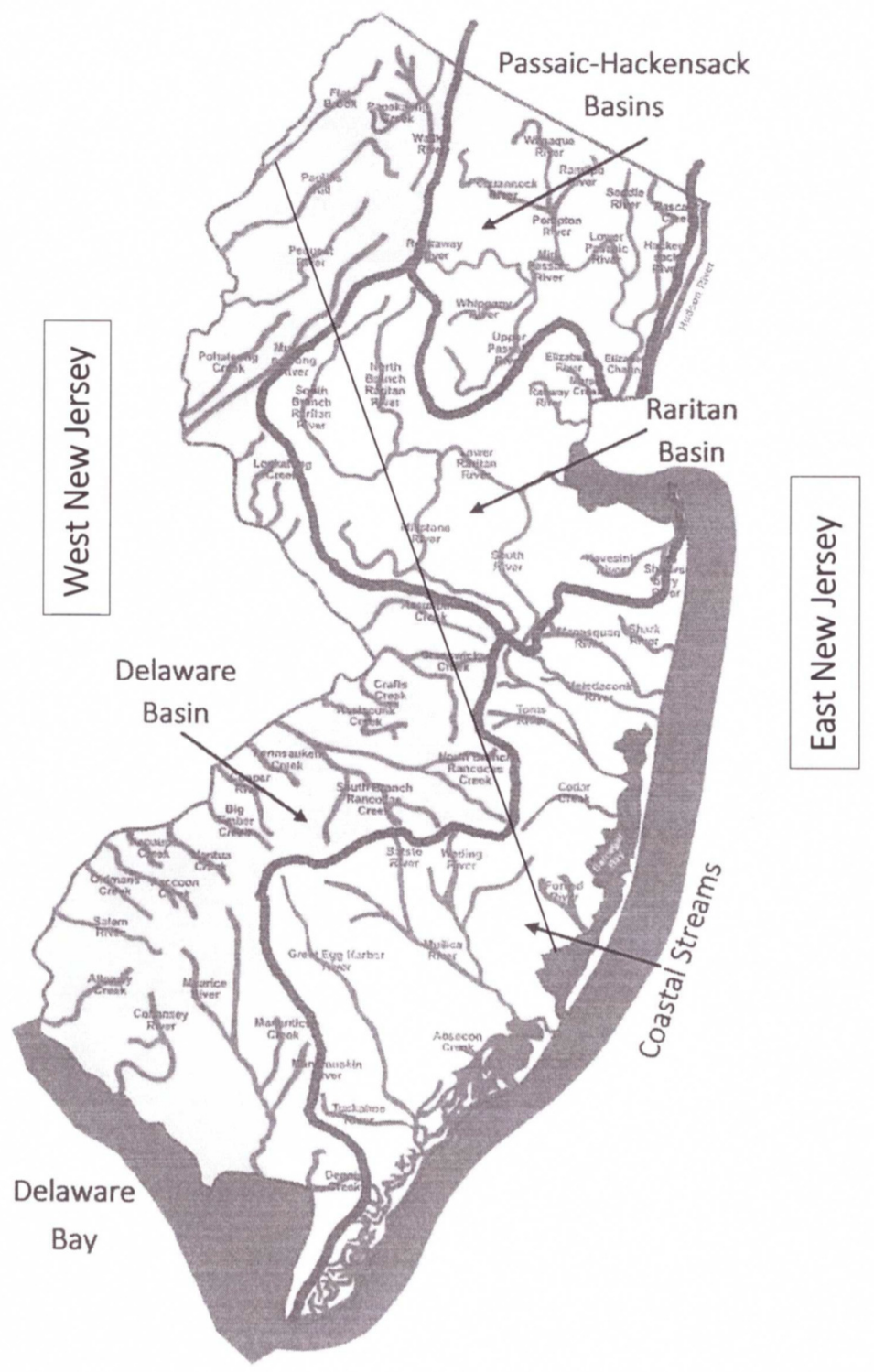

\footnotetext{
${ }^{2}$ Robert S. Grumet, The Munsee Indians: A History (Norman: University of Oklahoma Press, 2009). On the name Lenape, see note 9, below, and Grumet, Munsee Indians, 12-14.
} 
Within the context of land transfer patterns in the four river basins and Atlantic seacoast, this paper focuses particularly on data from the surviving deeds and related documents of Europeans and Lenapes in West Jersey and how their expectations changed over time. These documents provide the best evidence still extant of how the Lenapes exercised their power to retain sovereignty. Initially, the West Jersey colonists favored settlement along the Delaware River and lower reaches of its tributary creeks, lands on which Lenape groups including the Cohanseys, Narraticons, Mantes, Armewamese, and Rancocas had built their towns. The Europeans wanted this territory for access to travel and trade as well as to create plantations, farms, and villages. The representatives of European governments and trading companies expected full ownership of the land, sending written deeds signed by Lenape sachems back to their sponsors at home. The Lenapes were willing to receive gifts in exchange for permission to build trading forts and small farms, but expected to retain most of their land. While European settlers later took up inland tracts as their numbers expanded and the Lenape population declined, Lenapes still claimed large areas in 1758 despite earlier deeds. As we discuss in detail below, analysis of West Jersey records indicates that the Lenapes expected regular gifts, monitored boundaries, and assumed that conveyances became invalid unless settled promptly. They continued to share resources and live in the Pine Barrens and adjacent lands long after Europeans believed they had taken ownership.

The principal database for this paper comprises eighty-six West New Jersey land conveyances from Lenapes to European governments and individual colonists for land on the east side of the Delaware River and Bay, and on the southern New Jersey coast. Beginning around 1614, Dutch mariners and traders were the first Europeans to sail up the Delaware River. In 1624, the Dutch West India Company sent captain Cornelis Jacobsen May with colonists to settle at Matinicum (Burlington) Island. This settlement lasted only until 1626, when the company briefly consolidated 
the New Netherland colony at Manhattan. Nevertheless, trading continued in the Delaware from vessels and Fort Nassau, built near Big Timber Creek in 1626. Three years later, the Dutch West India Company changed its policy from focusing on trade to permit wealthy investors to purchase large territories from the Lenapes to establish patroonships, or plantation colonies. In 1631, the Dutch attempted to establish a patroonship called Swanendael at Cape Henlopen in Delaware, with plans for another patroonship at Cape May. The Lenape group at Cape Henlopen, the Sickoneysincks, destroyed Swanendael and killed all thirty-two residents after the Dutch posted a sign claiming sovereignty over a broad territory and gave most of their goods to Lenapes for more land at Cape May. The Sickoneysincks sought to forestall a European invasion of their country such as had occurred in Virginia and New England. ${ }^{3}$

With superior numbers and willingness to use violence if necessary, Lenape communities, including the Sickoneysincks, retained sovereignty and control in the region until after 1680. Indeed, in 1671 nearly all of the estimated 858 Europeans in the Delaware Valley dwelled on the west bank of the river. They included Swedes and Finns who came with the New Sweden expeditions beginning in 1638 and lived mostly from the current locations of Wilmington to Philadelphia; Dutch soldiers who manned forts before and after New Netherland conquered New Sweden in 1655, along with officials and their families who resided primarily in and around New Castle; and English soldiers, officials, and families who came after 1664 when James, Duke of York's forces took New Netherland, which became New York, New Jersey, and the Delaware colony. The Duke in turn granted New Jersey to Sir John Berkeley and Sir George Carteret, who in 1674 divided the

\footnotetext{
${ }^{3}$ C.A. Weslager and A.R. Dunlap, Dutch Explorers, Traders and Settlers in the Delaware Valley 1609-1664 (Philadelphia: University of Pennsylvania Press, 1961), 43-81, 121-27; "Instructions for Willem Verhulst, Director of New Netherland [January 1625]," in A.J.F. van Laer, trans. and ed., Documents Relating to New Netherland, 16241626 (San Marino, CA: Henry E. Huntington Library and Art Gallery, 1924), 51; Jean R. Soderlund, Lenape Country: Delaware Valley Society Before William Penn (Philadelphia: University of Pennsylvania Press, 2015), 35-54.
} 
proprietorship in half, with Berkeley taking West New Jersey, which he promptly sold to the Quaker John Fenwick in trust for another Quaker, Edward Byllynge. Complicated financial deals and lawsuits arising from a dispute between Fenwick and Byllynge resulted in two initial Quaker settlements in West New Jersey: Salem founded in 1675 and Burlington in 1677. The proprietary colony of West New Jersey lasted until 1702 when the proprietors of both East and West New Jersey surrendered their right of government to the English Crown, forming the unified royal colony of New Jersey. The proprietors did not yield their rights to land they had purchased from the Lenapes and continued to negotiate for additional territory after $1702 .^{4}$

Many of the transactions between the Lenapes and colonists were recorded and are available on microfilm at the New Jersey State Archives in Trenton. They can be accessed through William Nelson's Patents and Deeds and Other Early Records of New Jersey, 1664-1703 and the typescript index New Jersey Colonial Conveyances at the State Archives and online. $\frac{5}{}$ To supplement these records for the Delaware Valley and southern New Jersey coast, we used a wide variety of other sources to locate Lenape conveyances not found in deed books in the State Archives. For the pre1664 period, records of New Netherland, New Sweden, and the Duke of York's colony provide evidence of Lenape-European negotiations. Some deeds have been published, but in other cases we know only that Lenapes gave permission to build forts and farms, but have no written deeds. We

\footnotetext{
${ }^{4}$ Maxine N. Lurie, "The Reality of Empire: New Englanders on the Ground in Seventeenth Century East Jersey," New Jersey Studies: An Interdisciplinary Journal 3 (Summer 2017): 1-2 http://dx.doi.org/10.14713/njs.v3i2.82 ; John E. Pomfret, The Province of West New Jersey 1609-1702: A History of the Origins of an American Colony (Princeton, NJ: Princeton University Press, 1956), 57-58, 60-61, 71-85, 103-4; Soderlund, Lenape Country, 55-67, 112-20, 141-48. ${ }^{5}$ Recorded deeds, New Jersey State Archives (NJSA), Trenton; William Nelson, Patents and Deeds and Other Early Records of New Jersey, 1664-1703 (Paterson, NJ: The Press Printing \& Publishing Company, 1899); West Jersey Historical Project, The_NJ_Colonial_Conveyances.pdf, www.westjerseyhistory.org/docs/cc/index.shtml . For excellent introductions to New Jersey's land records, see John P. Snyder, The Story of New Jersey's Civil Boundaries 1606-1968 (Trenton: Bureau of Geology and Topography, 1969); Joseph R. Klett, "Understanding New Jersey's Geography in the Proprietary Period," Genealogical Magazine of New Jersey 89 (2014): 147-208; and Joseph R. Klett, Using the Records of the East and West Jersey Proprietors (Trenton: New Jersey State Archives, 2014) www.nj.gov/state/archives/pdf/proprietors.pdf .
} 
have included these unrecorded transactions such as Cornelis May's negotiations for Matinicum

Island because we know that a transaction took place whether it was written down and lost, or

preserved orally according to the normal Lenape practice. ${ }^{6}$ For the post-1664 period, Frank H.

Stewart's Indians of Southern New Jersey is an important source as the author provided transcripts

of deeds that he possessed or borrowed; two of these deeds can be found in his papers in the University Archives and Special Collections of Rowan University. The New Jersey Historical Society, Camden County, Gloucester County, and Salem County historical societies, and the Cape May County Genealogical Library also hold originals and copies of Lenape deeds, while published county and local histories offer references to deeds no longer extant, and county court minutes include some additional recorded deeds. ${ }^{7}$ Despite expanding our database to include oral as well as

\footnotetext{
${ }^{6}$ Edward Armstrong, ed., "Record of Upland Court; From the $14^{\text {th }}$ of November, 1676, to the $14^{\text {th }}$ of June, 1681," Memoirs of the Historical Society of Pennsylvania, vol. 7 (Philadelphia: J.B. Lippincott \& Co., 1860); Peter Stebbins Craig, 1671 Census of the Delaware (Philadelphia: Genealogical Society of Pennsylvania, 1999); Peter Stebbins Craig, The 1693 Census of the Swedes on the Delaware (Winter Park, FL: SAG Publications, 1993); Stellan Dahlgren and Hans Norman, The Rise and Fall of New Sweden: Governor Johan Risingh's Journal 1654-1655 in Its Historical Context (Stockholm: Almqvist \& Wiksell International, 1988); B. Fernow, Documents Relating to the History of the Dutch and Swedish Settlements on the Delaware River, vol.12 (Albany: Argus Publishing Company, 1877); Charles T. Gehring, trans. and ed., New York Historical Manuscripts: Dutch, Volumes XVIII-XIX Delaware Papers (Dutch Period) (Baltimore: Genealogical Publishing Co., Inc., 1981); Charles T. Gehring, ed., New York Historical Manuscripts: Dutch, Vols. XX-XXI, Delaware Papers (English Period) (Baltimore: Genealogical Publishing Co., Inc., 1977); Amandus Johnson, The Swedish Settlements on the Delaware: Their History and Relations to the Indians, Dutch, and English, 1638-1664, 2 vols. (Philadelphia: D. Appleton \& Company1911); Donald H. Kent, ed., Early American Indian Documents: Treaties and Laws, 1607-1789, Volume 1: Pennsylvania and Delaware Treaties, 16291737, gen. ed. Alden T. Vaughan (Washington D.C.: University Publications of America, Inc., 1979); Albert Cook Myers, ed., Narratives of Early Pennsylvania, West New Jersey, and Delaware 1630-1707 (New York: Charles Scribner's Sons, 1912); William Nelson, ed., The Indians of New Jersey (Paterson, NJ: The Press Printing \& Publishing Company, 1894); C. A. Weslager, The Delaware Indians: A History (New Brunswick, N.J.: Rutgers University Press, 1972).

${ }^{7}$ Frank H. Stewart, Indians of Southern New Jersey (Woodbury, NJ: Gloucester County Historical Society, 1932); Thomas Cushing and Charles E. Sheppard, History of the Counties of Gloucester, Salem and Cumberland, New Jersey (Philadelphia: Everts \& Peck, 1883); Isaac Mickle, Reminiscences of Old Gloucester or Incidents in the History of the Counties of Gloucester, Atlantic and Camden, New Jersey (Philadelphia: Townsend Ward, 1845); George R. Prowell, The History of Camden County, New Jersey (Philadelphia: L. J. Richards \& Co., 1886); H. Clay Reed and George J. Miller, eds., The Burlington Court Book: A Record of Quaker Jurisprudence in West New Jersey, 1680-1709 (Washington D.C.: American Historical Association, 1944); Edwin Salter, The History of Monmouth and Ocean Counties, Embracing a Genealogical Record of Earliest Settlers in Monmouth and Ocean Counties and their Descendants (Bayonne, NJ: F. Garner \& Sons, Publishers, 1890); James P. Snell and Franklin Ellis, History of Hunterdon and Somerset Counties, New Jersey (Philadelphia: Everts \& Peck, 1881); Lewis Townsend Stevens, The History of Cape May County, New Jersey from Aboriginal Times to the Present Day (Cape May, NJ: Press of the Star of Cape Publishing Company, 1897); Ewan M. Woodward and John F. Hageman, History of Burlington and Mercer
} 
preserved written conveyances, we believe additional deeds probably exist. In analyzing the West

New Jersey land conveyances below, we have used the actual texts of extant original and recorded deeds as well as evidence from other sources such as court documents and the Council of West Jersey Proprietors minutes.

The Lenapes, an Algonquian people, dominated the region that became New Jersey when Europeans first made sustained contact in the early seventeenth century. Lenape country stretched from what is now southern New York State through New Jersey, eastern Pennsylvania, and northern Delaware to Cape Henlopen. They lived in autonomous communities along creeks, rivers, and the Atlantic Ocean that governed themselves internally but allied with other Lenape towns for diplomacy and war. ${ }^{8}$ In New Jersey, the Munsees included the Minisinks, Tappans, Hackensacks, Raritans, Navesinks, and other Lenape communities who lived between the northern Delaware and Hudson river valleys and along the northern Atlantic shore. To the south and west, the Cohanseys, Narraticons, Mantes, Armewamese, and Rancocas resided and worked on tributaries of the lower Delaware River and Bay and the southern New Jersey coast. When asked their identity, they called themselves Lenape, which means an "ordinary, real, original" person. ${ }^{9}$

Counties, New Jersey (Philadelphia: Everts and Peck, 1883); Records of the Court of New Castle on Delaware 16761681 (Lancaster, PA: Wickersham Printing Co., 1904); copy of original deed from Paul W. Schopp.

${ }^{8}$ Richard Veit, "Setting the Stage: Archaeology and the Delaware Indians, a 12,000-Year Odyssey," in Maxine N. Lurie and Richard Veit, eds., New Jersey: A History of the Garden State (New Brunswick, N. J.: Rutgers University Press, 2012), 6-32; R. Michael Stewart, "American Indian Archaeology of the Historic Period in the Delaware Valley," in Richard Veit and David Orr, eds., Historical Archaeology of the Delaware Valley, 1600-1850 (Knoxville: University of Tennessee, 2014), 1-48; R. Michael Stewart, Chris C. Hummer, and Jay F. Custer, "Late Woodland Cultures of the Middle and Lower Delaware River Valley and the Upper Delmarva Peninsula," in Jay F. Custer, ed., Late Woodland Cultures of the Middle Atlantic Region (Newark: University of Delaware Press, 1986), 58-89; Dorothy Cross, Archaeology of New Jersey, 2 vols. (Trenton: Archaeological Society of New Jersey and New Jersey State Museum, 1941, 1956); Paul D. Boyd, "Settlers Along the Shores: Lenape Spatial Patterns in Coastal Monmouth County, 16001750” (Ph.D. diss., Rutgers University, 2005); Ilene Grossman-Bailey, “'The People Who Lived by the Ocean': Native American Resource Use and Settlement in the Outer Coastal Plain of New Jersey" (Ph.D. diss., Temple University, 2001); Catherine McCann, "Six Late Sites in Southern and Central New Jersey," Bulletin of the Archaeological Society of New Jersey (BASNJ) 13 (1957): 1-10; Anthony F. C. Wallace, "Woman, Land, and Society: Three Aspects of Aboriginal Delaware Life," Pennsylvania Archaeologist 17 (1947): 1-35.

${ }^{9}$ In the seventeenth century, when referring to Lenapes of other communities, Lenapes generally used their community names such as the Cohanseys and Armewamese. Recent scholars differ on terminology. Some refer to all people who lived from southern New York to northern Delaware as Lenapes, while others divide the group into Munsees 
Estimates suggest that at least 12,000 Lenapes lived throughout New Jersey prior to European arrival, but the numbers are difficult to verify because of the lack of documents and impact of epidemics and war. European diseases likely killed Lenapes even before Henry Hudson's arrival in 1609. After Dutch settlement of Manhattan in 1626, the population of Lenapes in northeastern New Jersey plummeted as a result of smallpox, other diseases, and war. Epidemics brought by the Dutch, Swedes, and English also killed many Lenapes of the Delaware Valley, though their decline was less immediate and severe because they avoided large-scale conflict. ${ }^{10}$

For many centuries before the Europeans came, the Lenapes had built their towns along waterways, claiming both sides of a stream. Like other Indians of North America, they held land cooperatively in communities, not as individuals. Each community held a specific territory that they could sell or refuse to sell without permission from external groups. Lenape socio-political structure was egalitarian and democratic. Sachems worked with the guidance of a council of elders and other leaders, retaining authority only if they followed the collective will of their people. Accordingly, sachems could not sign away rights to land without permission from their community. Lenapes

(approximately north from central New Jersey) and Unamis or Lenapes (south from central New Jersey). The names Munsee and Unami came into use only in the mid-eighteenth century, when English colonists and some Lenapes also used the name Delawares when referring to Lenapes. Grumet, Munsee Indians, 3-4, 12-14; Weslager, Delaware Indians, 31-49; Amy C. Schutt, Peoples of the River Valleys: The Odyssey of the Delaware Indians (Philadelphia: University of Pennsylvania Press, 2007), 7-30; Herbert C. Kraft, The Lenape-Delaware Indian Heritage: 10,000 B.C.A.D. 2000 (N.p.: Lenape Books, 2001), 205-352; Peter O. Wacker, Land and People: A Cultural Geography of Preindustrial New Jersey: Origins and Settlement Patterns (New Brunswick, N.J., 1975), 57-119; Daniel K. Richter, "The First Pennsylvanians," in Randall M. Miller and William Pencak, eds., Pennsylvania: A History of the Commonwealth (University Park: Pennsylvania State University Press and the Pennsylvania Historical and Museum Commission, 2002), 27-33; Soderlund, Lenape Country, 1-26. Marshall Becker incorrectly argues that the Lenapes in southern New Jersey were a different people from Lenapes in Pennsylvania in Marshall Joseph Becker, "Lenopi; Or What's in a Name? Interpreting the Evidence for Cultures and Cultural Boundaries in the Lower Delaware Valley," BASNJ 63 (2008): 11-32 and "Mehoxy of the Cohansey Band of South Jersey Indians: His Life as a Reflection of Symbiotic Relations with Colonists in Southern New Jersey and the Lower Counties of Pennsylvania," BASNJ 53 (1998): 40-68. For evidence that Lenape communities such as the Cohanseys and Armewamese lived and held territory on both sides of the Delaware, see Soderlund, Lenape Country, 13-18, 40-42, 55-58, 72-82, 112-14, 125-48; Grumet, Munsee Indians, 159-60, 354 n.17; Wallace, "Woman, Land, and Society," 2-3.

${ }^{10}$ Kraft, Lenape-Delaware Indian Heritage, 389; Ives Goddard, "Delaware," in Bruce G. Trigger, ed., Handbook of North American Indians, vol. 15, Northeast (Washington, D.C.: Smithsonian Institution, 1978), 214; Soderlund, Lenape Country, 16-18. 
considered rivers and streams as highways rather than as obstacles or boundaries, traveling by canoe whenever possible to hunt, fish, gather shellfish, berries, and wood, visit neighbors, and conduct diplomacy, war, and peace. ${ }^{11}$

The early European explorers and colonizers also viewed the rivers as conduits, marking the Hudson and Delaware valleys as separate spheres of trade and settlement. From first contact, New Jersey was divided roughly by watersheds, reflected more formally after 1674 by the series of province lines drawn between East and West Jersey. Like the Lenapes, the early explorers and colonists traveled by water, as European settlement proceeded from the water's edge. ${ }^{12}$ Europeans preferred land with water access, for the most convenient mode of travel was by boat on New Jersey's bays, rivers, and coastal waters. The kind of craft they used depended on the natural conditions of these bodies of water, including their width and depth, and the presence of shoals. Overland travel on Indian trails was arduous, as it took more time and covered less territory. Colonists started building European-styled roadways in West Jersey only in the late seventeenth century. ${ }^{13}$

In exploring river systems to identify sites for settlement and trade, mariners chose craft according to their destinations and sailing conditions. Larger vessels, often faster, were less maneuverable than smaller ones. Scholar Charlotte Wilcoxen divides the kinds of vessels used in New Netherland in the seventeenth century into large and small types, each type described, and

\footnotetext{
${ }^{11}$ Soderlund, Lenape Country, 12-13, 23-24; Grumet, Munsee Indians, 17, 24-39; Grossman-Bailey, "People," 259-65, 289-331; Stewart, "American Indian," 1-48; Veit, "Setting the Stage," 6-32.

${ }^{12}$ Donna Merwick, The Shame and the Sorrow: Dutch-Amerindian Encounters in New Netherland (Philadelphia: University of Pennsylvania Press, 2006), 24-31; Grumet, Munsee Indians, 35, 45-67; Maxine N. Lurie and Peter O. Wacker, eds., Mapping New Jersey: An Evolving Landscape (New Brunswick, N. J.: Rutgers University Press, 2009), 48-50.

${ }^{13}$ Wheaton J. Lane, From Indian Trail to Iron Horse: Travel and Transportation in New Jersey, 1620-1860 (Princeton, NJ: Princeton University Press, 1939), 343-39; Charles S. Boyer, Rambles through Old Highways and Byways of West Jersey (Camden, NJ: Camden County Historical Society, 1967), 1-8; Reed and Miller, Burlington Court Book, 19, 96, $99,115$.
} 
where they were used. The larger vessels included the ship, fluyt (flyboat), frigate, and jacht (yacht). They traveled across the ocean, along the coast, up bays and estuaries, and into wider rivers. The smaller vessels included the bark, galiot (or ketch), schooner, and sloop. These too could navigate coastal waters, bays, and estuaries, but could also sail up narrower, more shallow rivers. The smallest vessels were scows, prams, and canoes, which could travel even farther upstream. ${ }^{14}$

When the English sea captain Henry Hudson, exploring for the Dutch United East India Company, sailed the Halve Maen (Half Moon), a jacht, along the North American coast in 1609, the crew took soundings along lower Delaware Bay. From this, Robert Juet, a ship officer, opined that further exploration of the bay would require a pinnace (a small boat with a sail and oars). Later, in New York harbor, they explored Raritan Bay and Newark Bay in the jacht, but went ashore in a small boat, leaving the jacht in deeper water. ${ }^{15}$ The explorers and traders who followed Hudson in quest of furs for Dutch merchants-Cornelis May, Hendrick Christiaensen, and Adriaen Blocksailed jachts on bays and large rivers but turned to smaller vessels like sloops, shallops, prams, and canoes to go farther upstream. ${ }^{16}$

Dutch mariners used maps to document their travels for European investors and colonizers, depicting major bays and rivers, often with different names than today's designation or with no designation at all. ${ }^{17}$ Many of the names reflected their understanding or misunderstanding of Lenape place names. The discussion below of how these explorers unveiled knowledge of New Jersey's

\footnotetext{
${ }^{14}$ Charlotte Wilcoxen, "Ships and Work Boats of New Netherland, 1609-1674,"in Nancy Anne McClure Zeller, ed. A Beautiful and Fruitful Place: Selected Rensselaerswijck Seminar Papers (Albany, NY: New Netherland Publishing, 1991), 53-72.

15 Wilcoxen. "Ships and Work Boats," 60; Robert Juet, Juet's Journal: The Voyage of the Half Moon from 4 April to 7 November, 1609 (Newark, NJ: New Jersey Historical Society, 1959), 25, 28-29.

${ }^{16}$ Wilcoxen. "Ships and Work Boats," 60, 67; Simon Hart, The Prehistory of the New Netherland Company: Amsterdam Notarial Records of the First Dutch Voyages to the Hudson ([Amsterdam]: City of Amsterdam Press, 1959), 17-38.

17 Anonymous, Northeast Coast, 1611, Seventeenth Century Pennsylvania Maps. Online at www.mapsofpa.com/antiquemaps1.htm (viewed January 2018).
} 
coast and river systems provides the most recent names for these features based on their placement and shape on the early seventeenth-century maps compared with modern maps. The earliest map, drawn in 1611 by an anonymous mapmaker, depicted the Raritan, Newark, and Delaware bays and probably the Navesink Estuary. While Adriaen Block's 1614 map noted only these locations, Cornelis Hendricksen's map of 1616 also showed the Passaic River, Raritan River and its Matawan River tributary, Navesink Estuary, Shrewsbury Estuary, Barnegat Bay, and Great Bay of the Mullica River. In addition, Hendricksen portrayed several streams along the Jersey shore, including the Metedeconk River, Toms River, and the Mullica with its Wading River and Batsto River tributaries. He also depicted the Maurice River and possibly the Big Timber Creek and Cooper River tributaries of the Delaware River. ${ }^{18}$

The Lord Baltimore map and those of Johannes de Laet and Jean Guerard of Dieppe in the 1630s added no new information about the bays and rivers of New Jersey. More precise maps appeared only in the 1650s, including Nicolaas Visscher's Novi Belgii, Novaeque Anglia nec non Partis Virginiae Tabula in 1655. Visscher added, to what was already known, the South River tributary of the Raritan, the Hackensack River, and Saddle River and Pompton River tributaries of the Passaic, but only the Manasquan River and Barnegat Bay along the Jersey shore. Oddly, he left out the Mullica and its tributaries and other Jersey shore rivers that had been depicted in earlier maps. Visscher added, however, many rivers not yet depicted along the Delaware Bay and River, including the Cohansey River and possibly the Menantico Creek tributary of the Maurice River on Delaware Bay and, from south to north along the Delaware River, the Salem River, Oldmans Creek, Raccoon Creek, Big Timber Creek, Cooper River, Pennsauken Creek, Rancocas Creek with its North and

\footnotetext{
${ }^{18}$ Online at www.mapsofpa.com/antiquemaps1.htm (viewed January 2018); Weslager and Dunlap, Dutch Explorers, 43-46.
} 
South Branch tributaries, Assiscunk Creek, Blacks Creek, Crosswicks Creek, and Assunpink Creek.

At about the same time, Swedish engineer Peter Lindeström depicted the same tributaries on his map of Delaware Bay and River. ${ }^{19}$

This European exploration and mapmaking of New Jersey's bays, rivers, and coast coincided with and facilitated Dutch, Swedish, and English efforts to buy up Lenape lands to establish colonies. The Hackensack River, Passaic River, and most of the Raritan River drain northern and eastern New Jersey—-the region that became East Jersey in 1674—while the Delaware Bay, Delaware River, and the South Branch of the Raritan drain West Jersey. Coastal streams drain both regions, with East Jersey to the north and West Jersey to the south. Regardless of which waterways were involved, the Europeans sought and obtained deeds to Lenape lands in a consistent temporal and spatial pattern, starting in the bays (or ocean) into which the streams empty, then up their lower reaches, to their middle reaches, then to their source areas and finally expanding out into their interior uplands.

Access to Munsee territory, or East Jersey, was through Newark Bay to the Hackensack and Passaic rivers and their tributaries, and through Raritan Bay to the Raritan River and tributaries. Data from William Nelson's Patents and Deeds and Other Early Records of New Jersey, 1664-1703 and the typescript index to New Jersey Colonial Conveyances at the State Archives and online, and important secondary sources provide an outline of how the pattern of conveyances unfolded in East Jersey. ${ }^{20}$ In the Hackensack River watershed, the first Dutch purchase from the Munsees was for

\footnotetext{
${ }^{19}$ Online at www.mapsofpa.com/antiquemaps1.htm (viewed January 2018); Peter Lindeström, Geographia Americae with an Account of the Delaware Indians Based on Surveys and Notes Made in 1654-1656, trans. and ed. Amandus Johnson (Philadelphia: Swedish Colonial Society, 1925), 156-57.

${ }^{20}$ Nelson, Patents; West Jersey Historical Project, The_NJ_Colonial_Conveyances.pdf, www.westjerseyhistory.org/docs/cc/index.shtml ; Grumet, The Munsee Indians; Boyd, "Settlers"; Richard Veit and Charles A. Bello, "Sundry Species of Trading Goods': A Comparative Study of Trade Goods Represented in Colonial Deeds and Archaeological Sites from Monmouth County, New Jersey," BASNJ 57 (2002): 66-71. The discussion of East Jersey deeds that follows is based on our database of deeds including date, location, and names of Lenapes and colonists involved in the transaction. These data permit identification of spatial and temporal patterns by river system. For the West Jersey transactions discussed in much greater detail below we have used the full text of the deeds and other sources.
} 
Pavonia, in 1630, the land on the southern or lower part of the Palisades around what are now Hoboken and Jersey City. ${ }^{21}$ Though the patroonship of Pavonia soon failed, it helped foment conflict with the Munsees as Europeans built farms on the west bank of the Hudson River. Director Willem Kieft of New Netherland triggered war in 1639 when he demanded tribute in wampum or corn from the Munsees. The resulting struggle ravaged the colony and left more than one thousand Munsees dead. Continued conflict in the 1650s and the spread of European disease undermined the ability of Munsees to challenge efforts of Europeans to expropriate their land. ${ }^{22}$

The English, after their takeover of New Netherland in 1664, purchased the lands on Newark Bay, into which the Passaic and Hackensack rivers empty, and three years later acquired the land between the Hackensack River and the lower reaches of the Passaic River, as far upstream as its Saddle River tributary. They purchased the entire length of the Hackensack River to its source in Haverstraw in 1671, and the land between the upper Hackensack River and the middle reaches of the Passaic River in 1677. The Munsees sold what is now northern Bergen County and all of Passaic County as far as the New York state line in 1680 and the land southward into the Hackensack Tract in 1685. The sachems yielded the territory above the Falls of the Passaic in what is now Paterson in 1694 and 1695, including the Passaic River above the Falls along with the lands around its Pequannock River tributary. Finally, a second conveyance in 1710 ceded northern Bergen County and all of Passaic County. ${ }^{23}$

In the Raritan basin, the Dutch purchased land on Raritan Bay between 1651 and 1664, including the Monmouth shore, the land to the north across from Staten Island, and the land at the mouth of the Raritan River. But most of the transfers on the Raritan began with the English, who

\footnotetext{
${ }^{21}$ Grumet, Munsee Indians, 52-53; Nelson, Indians, 102; Nelson, Patents, 1.

${ }^{22}$ Grumet, Munsee Indians, 53, 56-106; Andrew Lipman, The Saltwater Frontier: Indians and the Contest for the American Coast (New Haven: Yale University Press, 2015), 126-30; Merwick, Shame and the Sorrow, 137-50.

${ }^{23}$ Grumet, Munsee Indians, 118-22, 178, 200, 220; Nelson, Indians, 109-12; Nelson, Patents, 7, 17.
} 
between 1681 and 1688 obtained much of the river and its upstream tributaries. These sales also included more upstream parts of the main Raritan channel, as well as the Millstone River and its Lamington River tributary (1681). The English also purchased the South River tract on one of the Raritan's lower tributaries. A second spurt of land purchases along the Raritan's upstream tributaries occurred between 1700 and 1703. These included more of the Millstone River as far as North Brook and Rocky Brook (1700), the North Branch of the Raritan River to Peapack and the Blue Hills (1701), and yet more of the Millstone River as far as Cranbury Brook and even Rocky Brook (1702). In 1703 the Lenapes sold their land that crossed the divide from the upper branches of the Raritan River to Assunpink Creek, which empties into the Delaware River. Proprietors of East Jersey and West Jersey obtained cessions separately while continuing their conflict over where the Division Line should be located. ${ }^{24}$

On the northern Jersey shore, Dutch Director Peter Stuyvesant obtained a deed for the coast from Raritan Bay to Barnegat Bay in 1663. Two years later, the English acquired deeds for what are now Monmouth and Ocean counties. Subsequently, Lenapes signed deeds for territory progressively southward: the northern Monmouth County shore in the 1670s; the southern Monmouth County coast in the 1680s; and the Ocean and eastern Burlington County seashore in the early eighteenth century. Lenape land transactions in the interior followed sales along the coast, occurring as late as the $1740 s^{25}$

European efforts to purchase Lenape land in the Delaware basin followed a spatial pattern similar to Dutch and English purchases in East Jersey, though more complicated by struggle among

\footnotetext{
${ }^{24}$ Grumet, Munsee Indians, 85, 178, 200, 220; Nelson, Patents, 2, 49, 51, 57, 66, 73, 310; Snell and Ellis, History of Hunterdon and Somerset Counties, 559-60.

${ }^{25}$ Grumet, Munsee Indians, 178, 200, 220; Nelson, Indians, 104; East Jersey Liber I:401-2; Liber F:573; Liber C: 231; Liber H:221, NJSA; Stewart, Indians, 78; Salter, History of Monmouth and Ocean Counties, 33-34; Boyd, "Settlers," 192-207, 711-740.
} 
three competitors, the Dutch, Swedes, and English. Again, the colonists favored the prime territory on which Lenapes lived-where transportation, trade, and fertile soil were accessible —on the Delaware Bay and River, and on the lower reaches of streams. Here, large sailing vessels could anchor and send smaller craft to shore or up tributaries to trade European goods for furs and supplies. The colonists looked for fresh water resources and arable land to support farms and crafts. Over time, new immigrants and the descendants of earlier settlers moved to the middle and upper reaches of creeks. Some colonists took advantage of large reserves of timber and fuelwood, and used the flow of streams to power machinery of sawmills, gristmills, and ironworks in the Pine Barrens.

Table 1 sets out in diagram the temporal and spatial pattern of major Lenape-colonist deeds along the east bank of the Delaware River from the head of navigation for large vessels at the Falls (now Trenton) to Cape May. The deeds listed include agreements that the Lenapes made with representatives of the Dutch West India Company, governors of New Sweden, and leaders of West New Jersey. Also included in the table are the dates of some early smaller conveyances for which we have deeds or other evidence, as discussed below. As Table 1 shows, Lenapes gave permission for small settlements and trading forts along the east side of the Delaware as successive European governments made requests, the Dutch beginning in the 1620s at Matinicum Island and Fort Nassau, and in 1640s and early 1650s; the Swedes through the 1640s; and the English first at Varkens Kill (Salem River) in 1641, then from Cohansey Creek north to the Falls in the 1670s, and from the Cohansey to Cape May in 1688 and1693. English efforts to acquire interior lands progressed from the 1680 s to the 1740 s, culminating in 1758 with the separate colony-wide treaties of the New Jersey government with the Lenapes and Munsees.

\section{Table 1}

\section{Temporal Distribution of Lenape Land Conveyances below Trenton}




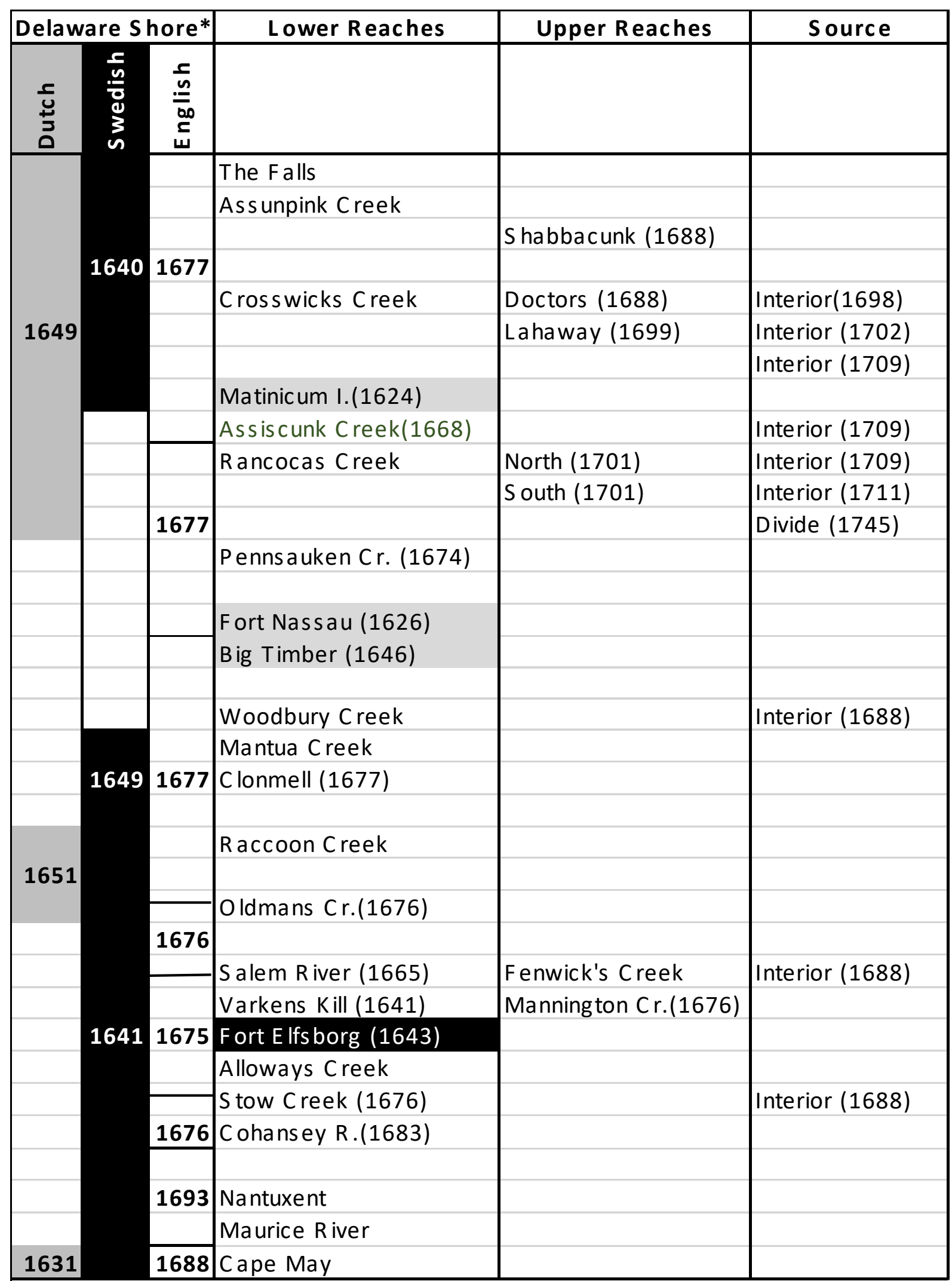

* Delaware Shore conveyances include some tributaries through their lower reaches 
As suggested in Table 1, despite efforts of successive groups of Europeans to obtain permanent rights to land along the Delaware, colonial claims in West Jersey remained tentative until after 1675. The Cohanseys, Armewamese, and other Lenape groups dominated the region through most of the seventeenth century and even after 1700 maintained considerable power through threat of violence, when necessary, against colonists who trespassed on their land and sovereignty. Despite periodic murders of whites who violated or misunderstood Lenape norms, the Delaware Valley avoided a major war until the mid-eighteenth century. Though Europeans wrote and preserved the written records of treaty conferences and land conveyances between Lenapes and colonists, the Lenapes dictated to a large extent the format and substance of these exchanges. With careful analysis and comparison with other sources, the deeds present a valuable source for understanding the evolution of Lenape motives, concerns, and expectations in dealing with the Dutch, Swedish, Finnish, and English traders and immigrants who craved territory. We look closely here at the evolution of land conveyances on the east bank of Delaware River and Bay to examine how the Lenapes only gradually yielded sovereignty as the number of settlers increased and the Lenape population declined significantly from disease.

The seventeenth-century treaties and land conveyances for West Jersey demonstrate the Lenapes' expectations when they agreed to allow Europeans access to land. Memory of the Sickoneysincks' destruction in 1631 of the Dutch colony of Swanendael discouraged Europeans from establishing large plantation settlements. ${ }^{26}$ The Lenapes had no intention of transferring all rights when they signed conveyances. They aimed to stay in their towns and retain free access for farming, hunting, fishing, and gathering. With an agreement, in return for annual gifts, they allowed the Europeans to establish a trading fort and small settlement to support trade. If the Europeans failed

\footnotetext{
${ }^{26}$ Gehring, Dutch, 340-41; Gehring, English, 11-12.
} 
to take up the land promptly and provide annual gifts, the rights were forfeited and the Lenapes were free to bargain with other Europeans. The Europeans also needed to be sure that they dealt with the true Lenape owner of the tract in question, which enhanced the importance of hiring an interpreter who knew the Lenape language, leadership, and laws. ${ }^{27}$

The Dutch, Swedish, and English colonizers learned fairly quickly their limitations in purchasing and controlling territory in the Delaware Valley, even as they competed with one another for dominance. The colonial governors wrote deeds covering much territory, signed by Lenapes, then sent the documents home to Europe as "proof" that they dominated the region. But they soon understood that the Lenapes retained control and that the deeds provided leases that they could keep only if renewed through annual payments. They also had to successfully resist military attack by other Europeans. $^{28}$

Prior to the founding of West New Jersey in 1674, the European population on the east bank of the Delaware remained sparse. Though Dutch patroons thought they had purchased Cape May in 1631, the Swanendael incident snuffed out that plan and the peninsula remained Lenape country. Dutch mariners continued to trade in the river, using Fort Nassau as a site for exchange, while English ships also occasionally visited to obtain furs. After New Sweden's governor Peter Minuit established Fort Christina in 1638, his successor Peter Holländer Ridder met with sachems to claim the entire Delaware Valley for Queen Christina. Ridder met in 1640 with sachem Kekesikkum to buy land on the east bank from Matinicum Island to the Falls and in 1641 sachem Wichusy signed a

\footnotetext{
${ }^{27}$ Soderlund, Lenape Country, 35-54, 109-10, 125-27, 130; Daniel K. Richter, Trade, Land, Power: The Struggle for Eastern North America (Philadelphia: University of Pennsylvania Press, 2013), 1-6; Seth Mallios, The Deadly Politics of Giving: Exchange and Violence at Ajacan, Roanoke, and Jamestown (Tuscaloosa: University of Alabama Press, 2006), 27-36.

${ }^{28}$ Soderlund, Lenape Country, 55-85.
} 
deed for the territory from Raccoon Creek south to Cape May. The Dutch occupied Fort Nassau, which lay between Matinicum and Raccoon Creek. ${ }^{29}$

In spring 1641, Ridder and the Dutch both had competition when merchants of New Haven on Long Island Sound sought to establish a colony on the Delaware. The Lenapes welcomed their trade and agreed to lease three locations, including land at Varkens Kill, which Ridder had negotiated three days before. Ridder obtained a statement from the sachem Wichusy that another Lenape had pretended to be his deputy in the English transfer. Nevertheless, twenty New Haven families settled at Varkens Kill, but could not prevent the new Swedish Governor Johan Printz, who arrived in February 1643, from constructing Fort Elfsborg adjacent to their farms, which he annexed into New Sweden. Between 1649 and 1652, the Swedes and Dutch both claimed additional large grants, but their actual tenure on the east bank remained limited to Swedish Fort Elfsborg, the tiny Varkens Kill settlement, and Dutch Fort Nassau. ${ }^{30}$

The Lenapes continued to control southern and western New Jersey, even as New Netherland in 1655 pushed out the New Sweden government and in turn English troops defeated New Netherland. Licenses to purchase land from the Lenapes and recorded Indian deeds provide the earliest evidence of European settlement on the east bank of the Delaware after the English takeover in 1664. Beginning in 1665, European colonists came from across the Delaware, clustering in four areas_-near Salem River, Raccoon Creek, Pennsauken Creek, and Matinicum Island. Some but not

\footnotetext{
${ }^{29}$ Peter Stebbins Craig, "New Sweden Settlers, 1638-1664 Part 1 (1638-1640)," Swedish American Genealogist 16 (1996): 75; Weslager, Delaware Indians, 119; Soderlund, Lenape Country, 61-62; Mark L. Thompson, The Contest for the Delaware Valley: Allegiance, Identity, and Empire in the Seventeenth Century (Baton Rouge: Louisiana State University Press, 2013), 68-69; A. R. Dunlap and C. A. Weslager, "More Missing Evidence: Two Depositions by Early Swedish Settlers," Pennsylvania Magazine of History and Biography 91 (1967): 35-45.

${ }^{30}$ C.A. Weslager, The English on the Delaware: 1610-1682 (New Brunswick, N.J.: Rutgers University Press, 1967), 91-106; Amandus Johnson, The Instruction for Johan Printz Governor of New Sweden (Philadelphia: Swedish Colonial Society, 1930), 68-70, 229-43; Thompson, Contest, 74-77; Gunlög Fur, Colonialism in the Margins: Cultural Encounters in New Sweden and Lapland (Leiden: Brill, 2006), 148-49.
} 
all obtained permits from New Jersey Governor Philip Carteret and submitted their deeds signed by Lenapes for recording.

The Cohanseys permitted individual settlement in the area that became Salem County despite having no overall treaty with the English proprietors. Dutch and French residents of New Castle first arrived in the mid to late 1660s. Foppe Jansen Outhout, a magistrate and tavern owner, obtained a deed from sachems Tospaminck and Wennaminck in 1665 but did not obtain a patent or have the deed recorded until 1669. In the meantime, in 1666, another New Castle resident Isaac Tayne alias L'Pierre obtained Carteret's permission and purchased rights from Wennaminck for land next to Outhout. ${ }^{31}$ Tayne sold one-half of his acreage to Machiel LaCroix (or Lacroy), whose sons Peter and Machiel Lacroy Jr. negotiated with sachems Tospaminck, Wennaminck, and Machkierck Allom for rights to lands nearby. The sachems, who received ten fathoms of wampum, three hogs, and one kettle, agreed to the deal at Outhout's house on the "Eastern Shoare called New Yernsey." In 1669, Machiel Baron, also a New Castle inhabitant, received Carteret's permission to purchase three hundred acres on Salem River. Though no recorded deed from the Lenapes exists, later court testimony indicates that he had the Cohanseys' approval. Swedes and Finns from the western shore also filtered east into Lenape territory, departing from the west bank of the Delaware River in rebellion against English land policies, including assessment of quitrents and expropriation of common lands. Lucas Peterson obtained a license from Carteret in 1668; three years later he negotiated a deed with the Cohanseys that mentioned two Finnish families as neighbors but for whom we have no deeds. ${ }^{32}$

\footnotetext{
${ }^{31}$ East Jersey Liber 1:9, 21, 33, 35, NJSA.

${ }^{32}$ Craig, 1671 Census, 72-73; Copy and translation, Indian Grant to Peter and Michael Lecroy, 1667, and Indian Deed to Luycas Peterson, 1671, Temporary Box 34 accessed December 2017, Stewart Collection, University Archives and Special Collections, Rowan University, Glassboro, N. J.; Stewart, Indians, 72-73; East Jersey Liber 1:22, 33, NJSA; New Castle Court Records, 387-89; Craig, 1693 Census, 138.
} 
After 1674, though the Lenapes remained dominant on the east bank of the Delaware, the legal and political situation changed for European colonists. During preparations for the Quaker colony of West New Jersey, Edward Byllynge and John Fenwick quarreled, with Fenwick taking his one-tenth of the West Jersey proprietorship to launch Salem, selling 148,000 acres to about 50 purchasers. The Quaker colonists began arriving in 1675, creating new challenges for the Lenapes, Dutch, French, Swedes, and Finns in residence. ${ }^{33}$

Like the Swedish and Dutch governors in the 1630s through 1650s, Fenwick sought to obtain rights to a large territory from Oldmans Creek south and east to the Cohansey River. He planned to carve up most of the land into plots for his investors. The Cohanseys could remain independent in their communities, but the old settlers would lose their land unless they shifted their allegiance from the Duke of York, represented by Governor Edmund Andros in New York, to Fenwick, the "Lord Proprietor." Until 1680, the Duke of York failed to transfer the power to govern West New Jersey to the Quaker proprietors, creating conflict between the Quakers and Andros, who jailed Fenwick twice for his refusal to recognize the Duke's authority. ${ }^{34}$

Fenwick met in treaty conference with Cohansey sachems on November 17, 1675, when Meopony, Alloways, Necosshehesco and her son Necomis, Saccatorey, and Mohutt signed a deed for land from Salem River to Canahockincke (probably Stow) Creek, from the Delaware River to the creek heads. The Cohanseys received woolen and linen apparel and "diverse other Commodities" for yielding rights to these lands "Exceepted allwayes out of this grant the Plantations in $\mathrm{w}^{\mathrm{ch}}$ they now Inhabite for and Unto such tyme only as they shall thinke fitt to Remove from the same." The

\footnotetext{
${ }^{33}$ Pomfret, West New Jersey, 57, 60-61, 71-85, 103-4; Soderlund, Lenape Country, 141-48.

${ }^{34}$ Pomfret, West New Jersey, 80-84. Until 1680, the Duke's New Castle court extended its jurisdiction to include the Salem area and the Upland court governed settlers north of Oldmans Creek.
} 
Lenapes were concerned about the increased immigration into their country and wanted to ensure that they would not be displaced. ${ }^{35}$

The old settlers were also worried about their land rights but could not obtain assurances from Fenwick in this first 1675 deed, for which Foppe Outhout and Machiel Baron served as witnesses. Outhout later testified that when Fenwick asked him to attend and serve as an interpreter, "the Indians then lykewyse would have had him drawe $\mathrm{y}^{\mathrm{e}}$ wrytings but that mayo ${ }^{\mathrm{r}}$ fenwike Refused that \& drewe the wrytings himselfe." According to Outhout, the sachems wanted Fenwick to recognize their previous grants to Outhout, Baron, and other old settlers, that the rights the Cohanseys gave Fenwick "Except[ed] Such Lands as they had Sould \& disposed of before." This "distinction," Outhout said, "was by $\mathrm{y}^{\mathrm{e}}$ Indians made." Though this exception did not enter the Fenwick deeds, old settlers generally kept the lands they had obtained from the sachems. ${ }^{36}$

Despite this first deed, Salem's founder had to meet twice more with sachems to confirm this purchase. Two concerns apparently required the repeated meetings: did all of the true Indian proprietors agree to the transfer and did Fenwick pay enough goods?

In the first line of the November 1675 deed, Fenwick named Mehocksett, a Cohansey sachem and major Lenape leader who met in treaty conferences with colonists on both sides of the Delaware. Mehocksett signed neither this deed nor the supplementary agreement of January 8, 1676, which several other previous signatories failed to sign. In March 1676, Fenwick finally obtained a deed signed by Mohutt, Alloways, Meopony, Saccatorey, Necosshehesco, and Necomis, "the true \& undoubted owners (as by naturall Right \& Interst).” This time Mehocksett was unnamed in the deed, but he witnessed the document as "the King" along with his brother Opur, two other Lenapes,

\footnotetext{
${ }^{35}$ Deed, Meopony et al. to John Fenwick, Nov. 17, 1675, MG3 \#4, New Jersey Historical Society.

${ }^{36}$ Deed, Meopony et al. to John Fenwick, Nov. 17, 1675; New Castle Court Records, 387-89.
} 
Fenwick's daughter Elizabeth Adams, and seven European men. Fenwick wanted to ensure that both Lenape and English leaders recognized the document. ${ }^{37}$

Adequate payment for this large tract was also a concern of the Cohanseys. The November 1675 deed vaguely mentioned clothing and other goods, while the January 1676 document noted that not all of those articles had yet been paid and so the sachems would instead accept a piece of cloth and four guns, the final two guns to be paid when all of the sachems, including Mehocksett, agreed to the deal. The final deed, which the six Cohansey proprietors signed and Mehocksett witnessed, described the payment as "a good \& valluable Quantitye of Rum tradeing cloath Shirts hoase shoes Gunnes lead pouder and other English Apparrell \& Commodities well \& truely payd unto us by John Fenwick."38

Fenwick found negotiations with the Cohanseys difficult, though he managed to obtain deeds more directly for two other sections he identified for his colony. On February 6, 1676, he obtained a deed for the territory known as Little Cohansey and Great Cohansey situated south and east along the Delaware River between Canahockincke Creek and Cohansey River, and into the mainland to their heads. He named Mehocksett again, with Mohutt, Newsego, Chochanahan, and Terucho as the "true \& undoubted Owners (as Natives)" but only Chochanahan, Mohutt, and Terucho signed. The sachems received rum, cloth, and other parcels of goods. On March 2, 1676, Fenwick acquired rights for the territory between Salem River and Oldmans Creek from Tospaminck and Wennaminck, who had sold lands to some of the old settlers, including Outhout and Taine. Like the other Fenwick documents, this deed said nothing about the rights of previous European settlers. Though Mehocksett signed none of the Fenwick deeds, he was involved in land transfers adjacent to the Fenwick colony.

\footnotetext{
${ }^{37}$ Agreement of Indians with John Fenwick, Jan. 8, 1675/6, MG3 \#6, New Jersey Historical Society; Stewart, Indians, 63-64; Salem Deeds \#1: 42, NJSA (dated March 14, 1676 "New Stile”).

38 Salem Deeds \#1: 42, NJSA.
} 
He was named in the1677 deed to the West Jersey proprietors for land between Oldmans and Big Timber creeks, for which only a recorded abstract and not a signed deed exists. In 1693, Mehocksett was in fact the first of six sachems who signed over the territory between the Cohansey and Maurice rivers to Jeremiah Basse for the West New Jersey Society in England. This record of land conveyances from 1675 to 1693 suggests that the colonists recognized Mehocksett as the primary sachem of southern New Jersey but he was careful to sign over only territory of which he was a true owner. $^{39}$

In 1677, Byllynge and trustees established West New Jersey north of Oldmans Creek, founding the first settlement at Burlington then expanding to Gloucester and Cape May. They initially purchased a large territory along the Delaware and settled on land adjacent to streams. The West Jersey commissioners engaged the Swedes Israel Helm, Peter Rambo, and Lasse Cock as interpreters to purchase rights for the two tracts between Oldmans and Big Timber creeks, and between Big Timber and Rancocas creeks. Hendrick Jacobs Falkenburg, a native of Holstein in what today is Germany, though associated with the Swedes, helped the Quakers purchase land from Rancocas Creek to Assunpink Creek. After the Quaker proprietors in 1680 obtained the Duke of York's right of government, they incorporated Salem into the colony, formed a provincial government seated at Burlington, and established county courts. ${ }^{40}$

As in the Salem area, European colonists had established farms in the area north of Oldmans Creek prior to the Burlington Quakers' arrival. With a 1668 permit from Governor Carteret, Swedes and Finns moved from the west bank of the Delaware to settle primarily between Oldmans and

\footnotetext{
${ }^{39}$ Salem Deeds \#1: 20; West Jersey Book B, Pt. 1: 3, 325, NJSA; Deed, Indians to John Fenwick, March 2, 1676, MG3 \#8, New Jersey Historical Society.

${ }^{40}$ West Jersey Book B, Pt. 1: 3-4, NJSA; Pomfret, West New Jersey, 124-35; Wacker, Land and People, 283-98; Reed and Miller, Burlington Court Book, xxxi-xxxvii; Samuel Smith, The History of New-Jersey, $2 \mathrm{~d}$ ed. (Trenton, N.J.: William S. Sharp, 1877), 93-95; Craig, 1671 Census, 71-72.
} 
Raccoon creeks. Hans Hopman and sons, Peter Jönsson Halton, Måns Jönsson Halton, and Jöns Gustafsson established households there by 1673 and in November 1676 obtained a deed from the Lenapes Awsawit, Oppeck Jan, and Kunnuckle. By the spring of 1677, according to the Upland Court census, Lars Andersson Kolman, Olle Dericksson, Pål Pålsson Corvhorn, and Will Bromfield also resided in the area, and soon after interpreter and Indian trader Israel Helm settled on 600 acres at Clonmell Creek. The Burlington Court in 1684 summoned these old settlers or their heirs to produce documentation for their claims. The court accepted most of their titles, perhaps with confirmation by the Lenapes for some, but reduced Helms's holdings to 100 acres. A small group of old settlers had started farms on the north side of Pennsauken Creek prior to 1677, most certainly with the Lenapes' permission, but Burlington Court required them to purchase land through the West Jersey public account or from other settlers. ${ }^{41}$

The cases of Pierre Jegou and Pieter Alrichs at Burlington demonstrate the complexity of landholding in early West Jersey. Even as European regimes changed, the Lenapes retained considerable power. According to testimony in several court cases, Jegou received a license in 1668 from Governor Carteret to operate a tavern at Lessa, or Lazy, Point on the northeast side of Assiscunk Creek at its confluence with the Delaware River. Jegou purchased the land from Cornelis Joris and two other Dutch men who had obtained permission from the Lenapes to build houses and farms. Pieter Alrichs, nephew of the former Dutch governor on the Delaware, testified that on his way from New York in 1668 or 1669 he had visited Lessa Point and "found that the said Dutch men had beene out with the Indians marking Trees." Jegou soon after bought the land from Joris and partners, but apparently failed to renew this permission from the Lenapes with gifts. According to Jegou, he was "plundered by the Indians, \& by them utterly Ruined as is wel knowne to all $\mathrm{y}^{\mathrm{e}}$ world." He abandoned

\footnotetext{
${ }^{41}$ East Jersey Liber 1: 19, NJSA; New Castle Court Records, 462-66; Craig, 1693 Census, 70-72, 76-82; Armstrong, Upland Court, 80; Reed and Miller, Burlington Court Book, 25-29.
} 
Lessa Point "to seek his Lyvelyhood \& to repaire his Losse in other places." Another colonist testified that Carteret in 1676 considered Jegou in default because he had promised to keep a tavern there, so the governor sent some cattle to Lessa Point "with intent to keep possession there for himselfe." 42

Carteret apparently failed to follow through: by 1677 , Jegou rented the land to Hendrick Falkenburg, whose excellent relations with the Lenapes helped Jegou safeguard his possession through diplomacy and gifts. The Dutch traveler Jasper Danckaerts described his November 1679 visit to Lessa Point, where Falkenburg "received us very kindly, and entertained us according to his ability" in his log cabin. ${ }^{43}$ In the same month, Jegou successfully prevented takeover by two Burlington settlers Thomas Wright and Godfrey Hancock. Because the Duke of York had not yet yielded governmental rights to the West Jersey Quakers, Upland Court heard the case. Jegou complained that Wright and Hancock had entered his land adjacent to the fledgling town of Burlington "and there have by force planted corne, cut timber for houses, mowed hay \& made fences," despite Falkenburg's warnings. The sitting Upland magistrates, three Swedes and one Holsteiner, were well versed in Lenape culture and respected precedent. They ruled that Jegou should keep Lessa Point, though it fell within the 1677 West New Jersey purchase, because he "had governo ${ }^{\mathrm{r}}$ Cartrets grants \& was in qui[e]t possession of ye Land, before Ever ye Land was sould by $\mathrm{s}^{\mathrm{r}}$ John Berckley unto Edward Billing and $\mathrm{y}^{\mathrm{t}}$ hee ye $\mathrm{s}^{\mathrm{d}}$ Jegou hath also bought ye Land and paid $\mathrm{y}^{\mathrm{e}}$ Indians for $y^{e}$ same." Jegou subsequently negotiated with the West Jersey assembly about his rights and sold his land to Thomas Bowman in $1683{ }^{44}$

\footnotetext{
${ }^{42}$ Craig, 1671 Census, 12-13, 69-72; Armstrong, Upland Court, 140-42; Reed and Miller, Burlington Court Book, 6768; Robert L. Thompson, Burlington Biographies: A History of Burlington, New Jersey, Told Through the Lives and Times of Its People (Galloway, NJ: South Jersey Culture and History Center, Stockton University, 2016), 19 n.29, 246.

${ }^{43}$ Bartlett Burleigh James and J. Franklin Jameson, eds., Journal of Jasper Danckaerts 1679-1680 (New York: Charles Scribner's Sons, 1913), 98-99.

${ }^{44}$ Armstrong, Upland Court, 138, 140-42; Reed and Miller, Burlington Court Book, 67-68; West Jersey Historical Project, The_NJ_Colonial_Conveyances.pdf, www.westjerseyhistory.org/docs/cc/index.shtml, 265.
} 
In addition to requiring Jegou's payments for Lessa Point, the Lenapes also protected their sovereignty in 1671, when Tashiowycan and Wywannattamo killed two Dutch servants whom Pieter Alrichs placed on Matinicum Island "to keep possession." Alrichs had obtained permission from the English to settle this island and two others nearby in 1667-1668, but apparently did not maintain good rapport with the Lenapes. While Tashiowycan admitted that he had killed the men out of revenge for his sister's death from disease, Lenapes during the decade after 1664 used periodic violence to protect their land from expropriation by the English government. ${ }^{45}$

Despite the multiple deeds that Lenape sachems signed between 1675 and 1714 for rights to much of their territory in West Jersey, and the migration of some Lenapes west into Pennsylvania and beyond, many stayed in their homeland and guarded their sovereignty. Their expectations evolved as disease took its toll and the European population surged. As discussed below, the Lenapes enforced their rules of land transfer until at least 1714 using the threat of violence against pacifist West Jersey Friends. The Lenapes continued to live on territory covered by large-scale deeds, required gifts from the Council of West Jersey Proprietors, obtained additional payments from individual colonists, remained watchful over boundaries, and used delaying tactics to resist further European expansion.

In the Salem area, the Lenapes remained in their towns between Oldmans Creek and Cohansey River as defined in the Fenwick deeds. On March 27, 1676, Accomes, Meopony, Saccatorey, and Alloways signed a receipt for John Pledger and Hipolit Lefever for land near Mannington Creek. Meopeny then sent "his man” Ten Hunt on April 10, 1676 to mark the bounds with Pledger and Lefever, providing a certificate that Accomes, Meopony, Saccatorey, and Ten Hunt

\footnotetext{
${ }^{45}$ Reed and Miller, Burlington Court Book, 68; Weslager and Dunlap, Dutch Explorers, 76-78; Soderlund, Lenape Country, 127-31. For physical evidence of early European settlement at Burlington Island, see Carolyn Dillian, Charles Bello, Richard Veit, and Sean McHugh, "Charles Conrad Abbott's Archaeological Investigations at a SeventeenthCentury Fur Trader's House on Burlington Island, New Jersey," in Veit and Orr, Historical Archaeology, 49-73.
} 
signed. ${ }^{46}$ Why Pledger and Lefever made this separate treaty with the Lenapes rather than depend on Fenwick's contemporaneous diplomacy is unclear, but it is possible that other settlers similarly worked with both the Lenapes and West Jersey surveyors to secure title. William Cooper in 1682 purchased Pyne Point in what is now Camden from a community of Lenapes who resided there, though the land was included in the 1677 West Jersey deed. The Lenapes continued to live nearby, for in 1703 they attended the funeral of Esther Spicer, who ran the ferry across Cooper River. ${ }^{47}$ Some other examples of colonists in West Jersey for whom we have written evidence of individual diplomacy include Hendrick Falkenburg in 1674 on Great Bay at the mouth of the Mullica River; John Roberts and partners in 1684 at Pennsauken Creek; John Ithell c. 1684 at Timber Creek; John Dennis and partners in 1688 at Cape May; interpreter Peter Erickson in 1694 near Cohansey River; and Samuel Hedge in 1699 at Pilesgrove. ${ }^{48}$ Perhaps most written evidence of individual diplomacy has been lost, while colonists without literacy and legal skills relied on oral agreements with the Lenapes.

The Council of West Jersey Proprietors, after its creation in 1688 to supervise land distribution, took primary responsibility for land negotiations with Lenape sachems. Meeting in Burlington, one of the council's first orders of business was to forbid anyone from purchasing land from the Lenapes without its consent. In an April 1689 letter, the council noted the many conferences its members had held with the Lenapes and the "chargeable treats bestowed upon them." ${ }^{49}$ Over

\footnotetext{
${ }^{46}$ Receipt, Accomes et al. to Hipolit Lefever and John Pledger, March 27, 1675 [1676] and Deed, Meopony et al. to Lefever and Pledger, April 20, 1676, originals in the Historical Society of Pennsylvania; reproduced in Albert Cook Myers, William Penn: His Own Account of the Lenni Lenape or Delaware Indians 1683 (Moylan, PA: Albert Cook Myers, 1937), 60-61.

${ }^{47}$ Mickle, Reminiscences, 53-54; Prowell, History of Camden County, 404-5; John Clement, Sketches of The First Emigrant Settlers in Newton Township, Old Gloucester County, West New Jersey (Camden, NJ: Sinnickson Chew, 1877), 293-97.

${ }^{48}$ West Jersey Book B: 644-45; Salem Deeds \#6:194; Salem Deeds \#1: 43; West Jersey Liber A-V: 526, NJSA; Stewart, Indians, 76; Affidavit, William Goodbody, Sept. 10, 1686, Gloucester County Court Records, Gloucester County Historical Society, Woodbury, NJ.

${ }^{49}$ Council of West Jersey Proprietors Minutes, microfilm, NJSA, Book 1:3, 26.
} 
ensuing years, the council appointed men to negotiate with the sachems, who sometimes agreed to sell land promptly but in other cases required extended negotiations and repeated payments. By 1703 , Lenapes increased their resistance to the land-grabbing campaign of the council and the West New Jersey Society of proprietors in England. From 1702 to 1714, these groups primarily targeted Lenape land north of the Falls of the Delaware. They completed large purchases but not without repeated conferences and payments to the sachems. ${ }^{50}$

In Burlington County, south of the Falls, Lenapes led by Sehoppy (also known as Mechmiquon or King Charles) lived in Crossweeksung, Weekpink, and nearby territory. In 1703, as settlers encroached on their lands, Sehoppy moved to clarify the eastern boundary specified in the 1677 deeds between Big Timber and Assunpink creeks. He protested that while the deeds mistakenly stated that the eastern border was the "uppermost head" of the creeks, in fact the boundary "ought to be according to a line that was afterwards actually run, by agreement made between the English and the Indians, and which comes lower upon the said creeks than the uppermost heads thereof." The Lenapes had marked the border with the colonists, who accepted it as the "Indian Line," and now Sehoppy successfully enforced it when the council agreed to change the deeds. ${ }^{51}$

Sehoppy also had to defend Lenape land in 1714, after an English colonist named John Wetherill used alcohol to obtain a deed from him for Weekpink. Governor Robert Hunter ruled that Wetherill purchased the land illegally, causing "the danger of a rupture with these Indians." The colonists who assisted Sehoppy argued that the incident "might be the occasion of a war in the country." 52 Though West Jersey leaders avidly obtained deeds to most Lenape lands prior to 1715 ,

\footnotetext{
${ }^{50}$ Grumet, Munsee Indians, 220-22, 231-32; Council of West Jersey Proprietors Minutes, Books 2 and 3.

${ }^{51}$ Council of West Jersey Proprietors Minutes, Book 2:16; Soderlund, Lenape Country, 178.

${ }^{52}$ Hunter's 1717 report included depositions indicating that the fraud occurred in February 1713/14; William A. Whitehead et al., eds., Documents Relating to the Colonial History of the State of New Jersey (New Jersey Archives), 2 series, 35 vols. (Newark, Trenton, and Paterson: various publishers, 1880-1931), ${ }^{\text {st }}$ ser., 4: 275-85; Richard Sears Walling, "The Coaxen Indian Plantation and Its Quaker Protectors: Assuaging Cultural Conflict" (Paper presented at the Quakers and American Indians conference, Bryn Mawr College, Nov. 11, 2016).
} 
they apparently followed the Lenapes' protocol for negotiating, including payments and fair practice, in part for fear of reprisals. While the sachems preferred peace, they were prepared to use violence to defend their communities.

After 1715, the Lenapes' political influence over the West Jersey colonists decreased as their population dwindled further from disease and westward migration. With the Walking Purchase of 1737, the Pennsylvania proprietors defrauded the Lenapes of their last stronghold on the west bank of the Delaware River. Some Munsees and southern Lenapes moved to central and western Pennsylvania, Ohio, and New York by 1755, but others joined together to meet with New Jersey authorities in conferences at Crosswicks in 1756 and 1758 and Easton (Pennsylvania) in 1758. The catalyst for these meetings was the outbreak of war in western Pennsylvania and attacks on settlers in northwestern New Jersey by Munsees who had left but not yielded their claims in the colony. ${ }^{53}$

In 1756, the New Jersey Indian commissioners instructed sachems from throughout the colony to bring in a list of properties they believed they still owned. The list the Lenapes presented at Crosswicks in February 1758 overlapped considerably with previous large-scale conveyances such as in southern New Jersey where Fenwick in 1675-76 negotiated for land from Oldmans Creek to the Cohansey River and Dr. Daniel Coxe and the West New Jersey Society obtained deeds in 1688 and 1693 for territory east from the Cohansey River and heads of Oldmans and Big Timber creeks to the Atlantic Ocean and south through Cape May. ${ }^{54}$ The sachems listed lands they believed the English forfeited (or had never purchased), as in the case of Dutch and Swedish claims a century before. Many properties on the Lenapes' 1758 list had not been settled by whites, and

\footnotetext{
${ }^{53}$ Schutt, Peoples, 81-93; Smith, History of N. J., 440-84; Grumet, Munsee Indians, 245-50, 262-69; Soderlund, Lenape Country, 184-95.

54 Indian Deeds to John Fenwick, MG3 \#4, \#5, \#6, \#8, New Jersey Historical Society; Salem Deeds \#1: 20 and 42, West Jersey Book B: 202-3, 325 and West Jersey Book B, Pt. 1: 3-4, NJSA; Stewart, Indians, 60-71.
} 
thus sales were nullified under Lenape norms. In the cases in which Europeans had taken up lands the sachems claimed, the colonists had probably failed to provide adequate payment, as with Jegou and Alrichs in 1668-1671.

The sachems asserted rights to lands for the most part in the upper reaches of several New Jersey rivers, described by them as having boundaries that "went to hollows, and small brooks, which had no certain names." From north to south, the Lenapes listed holdings on the Pompton River, a tributary of the Passaic River; the Raritan River and three of its major tributaries (the South Branch of the Raritan River, the Millstone River with its Cranbury Brook tributary, and South River with its Manalapan Brook tributary); the upper reaches of Crosswicks Creek and its Doctors Creek tributary; several watersheds along the coast, including those of Manasquan, Metedeconk, and Toms rivers; the lower Great Egg Harbor River and its Tuckahoe River tributary; and the Delaware Bay side of Cape May County.. The Lenapes also claimed lands in the South Jersey interior at Deerfield in Cumberland County and Pilesgrove in Salem County as well as vast tracts of the Pine Barrens, including some that became part of the Brotherton reservation. ${ }^{55}$

Because of the power shift since 1715 and the pressures of war, the Lenapes in 1758 agreed to yield most of their territory. At the 1758 Crosswicks Conference they appointed sachems Thomas Store, Moses Tatamy, Stephen Calvin, Isaac Still, and John Pompshire as a committee to negotiate with the commissioners of the New Jersey government. The sachems sought help from Philadelphia Quaker merchant Israel Pemberton to search the colonial land records to demonstrate the Lenape claims. Failing that, the sachems signed the September 1758 deed ceding all lands in central and southern New Jersey except Weekpink and several other tracts that individual sachems owned. They retained their rights to hunt and fish on uncultivated lands throughout the province,

\footnotetext{
${ }^{55}$ Smith, History of N. J., 442-46.
} 
rights they kept until 1832. In return, the Lenapes received the 3,000-acre Brotherton reservation in Burlington County. At the 1758 Easton conference, the Munsees released all lands north of the Raritan River for 1,000 Spanish pieces of eight. ${ }^{56}$

Seventeenth-century Dutch, Swedish, and English colonialists all claimed the eastern shore of the Delaware Valley. They battled each other for ascendancy, while in fact the Lenapes remained dominant, imposing their principles of land tenure and curtailing European settlement. The Lenapes required treaty protocol for land transactions, annual payments to renew leases, and renegotiation if lands sat unused. They expected to remain neighbors and share resources with the new immigrants. The Cohanseys' deals with Fenwick in 1675-1676, for example, provide insight into the sachems' expectations in signing deeds: they would remain in their homeland and receive adequate payments, and the Dutch, Swedes, and Finns to whom they had transferred small tracts would keep their property.

The West Jersey settlers placed priority on obtaining deeds along the Delaware Bay and River, and the lower reaches of tributaries, much like the Dutch and English in East Jersey. The Europeans prized territory convenient for trade, travel, and agriculture-thus sought areas the Lenapes held for similar reasons. Though, by the 1720s, European diseases gradually undermined the Lenapes' ability to withstand the tide of West Jersey colonists, many Lenapes remained and, in 1758 , held on to tracts along the upper reaches of streams and on the Atlantic coast. Sachems signed over most of these lands at Crosswicks, and a few people then moved to Brotherton, but others stayed at Weekpink and on lands at Crossweeksung, the Pine Barrens, and elsewhere in the colony. The

\footnotetext{
56 Smith, History of N. J., 440-84; Grumet, Munsee Indians, 262-69; Soderlund, Lenape Country, 188-95; Walling, "Coaxen": Edward McM. Larrabee, "Recurrent Themes and Sequences in North American Indian-European Culture Contact," Transactions of the American Philosophical Society, n.s., 66, pt. 7 (1976): 7-11; Tom Stores et al. to Friend Mr. Israel Pemberton, March 8, 1758, Philadelphia Yearly Meeting Indian Committee papers, Vol. AA1, 427, Quaker and Special Collections, Haverford College, Haverford, PA; Deed Book I-2, 85-92, NJSA; Stewart, Indians, $82-83$.
} 
1758 documents, like other expansive recorded deeds, included tracts the whites failed to settle promptly_and thus soon forfeited according to Lenape norms. With the provision to hunt and fish throughout the colony, Lenapes who remained in New Jersey preserved key economic rights.

Jean R. Soderlund is a professor of history emeritus at Lehigh University whose most recent book is Lenape Country: Delaware Valley Society before William Penn (University of Pennsylvania Press, 2015). She is currently researching and writing a history of colonial West Jersey, focusing on ethnic, gender, and economic relations among the Lenapes and immigrants. Her research for this article and the larger book project was assisted by a grant from the New Jersey Historical Commission, a division of the Department of State.

Claude M. Epstein is a professor of environmental studies emeritus at Stockton University. His academic publications deal with South Jersey river, wetland, and aquifer hydrology as well as its land use history. He is one of the founding faculty of Stockton University as well as founder of its undergraduate and graduate environmental studies programs. 